Journal of Engineering and Applied Sciences 15 (2): 574-580, 2020

ISSN: 1816-949X

(C) Medwell Journals, 2020

\title{
Estimation Comparison of Small-Scale Fisherman Decision on Choice Fishing Gear and Outboard Engine Power
}

\author{
${ }^{1}$ Abd. Rahim, ${ }^{1}$ Diah Retno Dwi Hastuti and ${ }^{2}$ Ulfah Syam \\ ${ }^{1}$ Development Economic Study Program, Faculty of Economics, \\ Universitas Negeri Makassar, Makassar, Indonesia \\ ${ }^{2}$ Department of English Education, Faculty of Teacher Training and Education, \\ Universitas Bosowa, Makassar, Indonesia
}

\begin{abstract}
Although, the policy of infrastructure support program from the local government of Barru district South Sulawesi province Indonesia in the form of fishing gear and outboard machine has been done but the change of income of catching business has not sufficient for household economy needs of small-scale fishermen. The purpose of this article is to estimate the small-scale fisherman's decision in selecting capture technology (fishing gear and outboard engine power) in Indonesia using model estimation model logit equation. The type of research used is explanatory method. The findings indicate that small-scale fisherman decision in choosing fishing gear is positively influenced by the income of catching business and the number of members covered and negatively by regional differences while the age of fisherman, education, side occupation and regional differences have no significant effect. Another case of fisherman decision in choosing the power of outboard engines is positively affected by the income of catching businesses and the number of members who are covered and negatively by different regions. While the age of fishermen, the number of family members, side jobs and regional differences have no significant effect.
\end{abstract}

Key words: Small-scale fishermen decisions, fishing gear, outboard engine power, estimation model, explanatory, regional

\section{INTRODUCTION}

Small-scale fishermen as small fisheries sub-sectors (Lopes and Begossi, 2011; Gebremedhin et al., 2013) are characterized as poor and marginalized (Ofori-Danson et al., 2013) but these small-scale fisheries support livelihoods and welfare more than 500 million people worldwide and as an important source of income in developing countries where millions of poor people live near the coast and nearly $97 \%$ of the world's fishermen are located (Pomeroy and Andrew, 2011; Barnes-Mauthe et al., 2013). In fishing by boat and simple fishing gear with capture technology in the form of outboard engines (Ele and Nkang, 2014) and as a group of livelihood people living in coastal or coastal villages. Small-scale fishermen consist of outboard motor and nonpowered motor while modern fishermen are using boats (Gebremedhin et al., 2013).

In general fishermen have a strong tendency to choose the same fishing gear and depend on changes in economic and biological conditions (Tveteras and Eggert, 2001) and supposedly with the technological advance of catching can help improve the catch, due to ship size and strength motors are strongly associated with variations in catch (Hilborn and Ledbetter, 1985; Salas and Charles,
2008) small-scale fishermen (Bolaky, 2006; Salas and Charles, 2008). The survival of small-scale fishermen in the Western coastal areas of Barru district in fulfilling their living needs in uncertain conditions due to seasonal changes (catching and famine). The existence of the season resulted in a change in catch production (Rahim et al., 2019) which resulted in a decrease in the income of fishermen in the business and household income (Rahim et al., 2018) and expenditure on household consumption (Mukarrama et al., 2013; Oladimeji et al., 2015 and Rahim et al., 2018) which is known as the economy of small-scale coastal fishermen household households. Although, the policy of infrastructure support program from the local government of Barru district South Sulawesi province Indonesia in the form of outboard machine and fishing gear has been done but the change of income of catching business has not sufficient for household needs, moreover the aid is only given to some fishermen who have an emotional connection with the donor (local government) such as a family relationship.

The objectives of the international fisheries policy through the Fisheries Committee (COFI) and the subcommittee are to support sustainable development and small fisheries protection in the context because 
small-scale fisheries generate two-thirds of all catches targeted for direct human consumption and provide $90 \%$ of employment in this sector (FAO., 2016) while the objectives of fisheries development in Indonesia include improving the welfare of fishermen, fish farmers and other coastal communities through the development of economic activities, quality improvement and quantity of resources sustainability, sovereignty and welfare (Regulation of the Minister of Maritime Affairs and Fisheries of the Republic of Indonesia No.18 /2014). At an international, intergovernmental level also conventions, accords and strategic policy development in diverse themes are also increasingly embracing or even targeting small-scale fisheries and their dependent communities (FAO., 2016).

Research on decisions analysis of fishermen has been extensively researched in several countries as investigated by Eales and Wilen (1986) in Northern California, Lane (1988) in British Columbia, Mistiaen and Strand (2000) in North Atlantic, Pradhan and Leung (2004) in Hawaii, Matiya et al. (2005) in Phipilina, Acquah and Abunyuwah (2011) in Ghana, Lopes and Begossi (2011) in Brazil, Saul and Die (2016) in West Coast of Florida. However, in the findings have not discussed the estimation comparison of small-scale fishermen decision in selecting fishing gear and outboard machine. In addition, the econometric approach with logit model analysis is limited studied for this issue. The study objective is to estimation comparison of traditional fisherman decision on choice fishing gear and outboard engine power by using econometric approach (Logit Model). We investigate the coastal areas of Barru district, South Sulawesi province, Indonesia as a case study.

\section{MATERIALS AND METHODS}

Geographically, Barru district is located between $4^{\circ} 5^{\prime} 49^{\prime \prime}-4^{\circ} 47^{\prime} 35^{\prime \prime}$ and $119^{\circ} 35^{\prime} 00^{\prime \prime}-119^{\circ} 49^{\prime} 16^{\prime \prime}$ latitude Fig. 1 about $102 \mathrm{~km}$ from capital of South Sulawesi, Makassar city. This area covers $1.174,72 \mathrm{~km}^{2}$ (contributed of $2.56 \%$ to South Sulawesi area). They are bordering to Pare-Pare city in the Northern part, Sidrap, Soppeng and Bone districts in the Eastern part, Pangkep district in the Southern part and Makassar Strait in the Western part. Furthermore, they are contains of seven sub-district including Tanete Riaja, Pujananting, Tanete Rilau, Barru, Soppeng Riaja, Balusu and Mallusetasi. This area has coastlines of about $78 \mathrm{~km}$ and covered by sandy beaches, mangroves, sea grass meadow, coral reefs, aquaculture ponds, rice fields, settlement and tourism areas.

Estimates of the small-scale fishermen's decision in choosing gear and outboard engines power in proxy from a qualitative dependent variable response (Gujarati et al., 2009) or logit models (DeMaris, 1992; Borooah, 2002). This model is based on the dependent variable model dichotomy. Logit Model derived from the probabilistic distribution to explain the qualitative response of the dependent variable or the cumulative logistic probability function model as follows:

$$
\mathrm{Pi}=\mathrm{F}(\mathrm{Zi})=\left(\beta_{0}+\beta_{0} \mathrm{X}_{\mathrm{i}}\right)=\frac{1}{1+\mathrm{e}^{-Z i}}=\frac{1}{1+\mathrm{e}^{-\left(\beta_{0}+\beta_{1} X_{\mathrm{i}}\right)}}
$$

Where:

e : Natural logarithm with value 2,718

$\mathrm{Pi}$ : Probability with a value between 0 and 1

$\mathrm{Z}$ : Between $-\infty$ and $+\infty$

Equation 1 can be manipulated by multiplying on both sides, resulting in the following equation:

$$
\left(1+\mathrm{e}^{-\mathrm{Zi}}\right) \mathrm{Pi}=\frac{1}{1+\mathrm{e}^{-\mathrm{Zi}}}=\left(1+\mathrm{e}^{-\mathrm{Zi}}\right)
$$

Or

$$
\left(1+\mathrm{e}^{-\mathrm{Zi}}\right) \mathrm{Pi}=1
$$

If Eq. 3 is divided by and then subtracted by 1, it will produce the following Eq. 3:

$$
\begin{gathered}
=\frac{\left(1+e^{-Z i}\right) P i}{P i-1}=\frac{1}{P i-1} \\
=e^{-Z i} \frac{1}{P i-1}-1=\frac{(1-P i)}{P i} \\
=\frac{1}{e^{-Z i}}=\frac{(1-P i)}{P i}
\end{gathered}
$$

Or

$$
\mathrm{e}^{-\mathrm{Zi}} \frac{\mathrm{Pi}}{(1-\mathrm{Pi}) \mathrm{Pi}}
$$

Equation 7 can be transformed into a natural logarithmic model, so as to produce Eq. 8 as follows:

$$
\mathrm{Z}_{\mathrm{i}}=\operatorname{Ln}\left(\frac{\mathrm{Pi}}{1-\mathrm{Pi}}\right)
$$

If $\mathrm{e}^{-\mathrm{Zi}}=\mathrm{Zi}$ then Eq. 8 can be written to:

$$
\mathrm{Zi}=\operatorname{Ln}\left(\frac{\mathrm{P}_{\mathrm{i}}}{1-\mathrm{Pi}}\right)=\beta_{0}+\beta_{0} \mathrm{X}_{\mathrm{i}}
$$

The type of research used is explanatory method that is estimating factors influencing small-scale fishing 


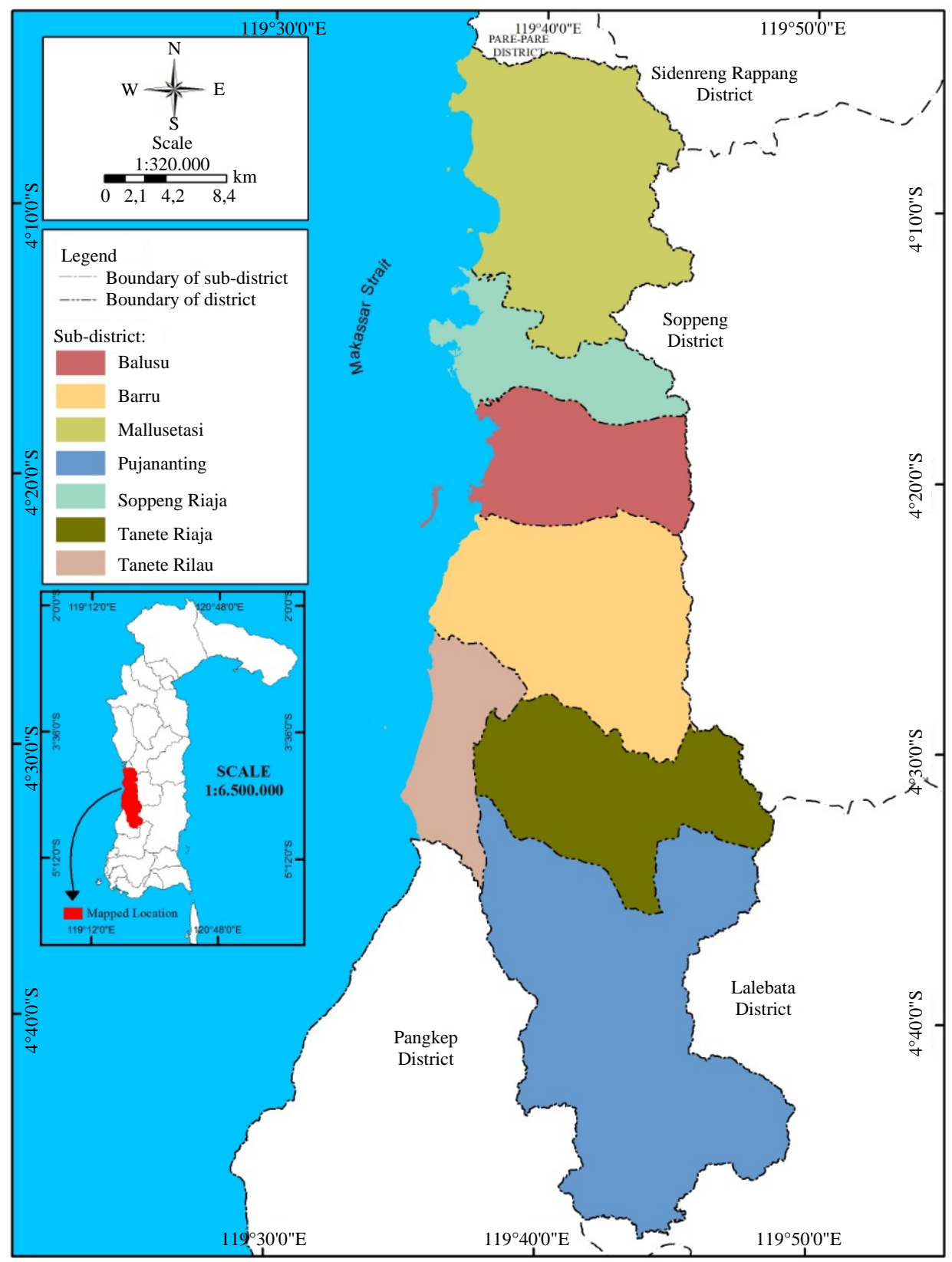

Fig. 1: Barru district, South Sulawesi province, Indonesia

decision in choosing fishing technology. The location of this research in the Western coastal area of Barru district of South Sulawesi Indonesia is determined purposively with consideration of having traditional fishermen in every sub-district and village directly adjacent to the Western coastal area and Sulawesi Strait. Primary data used in this study were obtained from small-scale fishermen in the West coastal area of Barru district as many as 124 samples of small-scale fishermen were chosen randomly. To test and analyze the estimation of factors influencing small-scale fishermen decision in choosing capture technology such as fishing gear (longline fishing and gill net) and outboard engine power such as 4.5 PK (Power Knot), 5-7 PK using model estimation of multiple regression equation by referring logit model estimation (DeMaris, 1992; Borooah, 2002) equation with exponential function as follows:

$$
\begin{aligned}
& \operatorname{SSFDCFG}\left(\frac{\mathrm{Pi}}{1-\mathrm{Pi}}\right) \beta_{0} \mathrm{FInc}^{\beta 1} \mathrm{FAg}^{\beta 2} \mathrm{FFEd}^{\beta 3} \mathrm{NDHM}^{\beta 4} \\
& \operatorname{SJF}^{\delta 1} \operatorname{TRSd}^{\delta 2} \mathrm{BSd}^{\delta 3} \operatorname{SRSd}^{\delta 4} \mathrm{BLsSd}^{\delta 5 \mu 1}
\end{aligned}
$$




$$
\begin{aligned}
& \operatorname{SSFDOEP}\left(\frac{\mathrm{Pi}}{1-\mathrm{Pi}}\right) \beta_{5} \mathrm{FInc}^{\beta 6} \mathrm{FAg}^{\beta 7} \mathrm{FFEd}^{\beta 8} \mathrm{NDHM}^{\beta 9} \\
& \operatorname{SJF}^{\delta 6} \mathrm{TRSd}^{\delta 7} \mathrm{BSd}^{88} \text { SRSd }^{\delta 9} \mathrm{BLsSd}^{\delta 10 \mu 2}
\end{aligned}
$$

The calculation of Eq. 10 and 11 can be converted to multiple linear by loglinear (DeMaris, 1992) or double log or natural logarithm (Gujarati et al., 2009) as follows:

$$
\begin{gathered}
\text { LnSSFDCFG }=\left(\frac{\mathrm{Pi}}{1-\mathrm{Pi}}\right)=\operatorname{Ln} \beta_{0}+\beta_{1} \mathrm{LnFInc}+\beta_{2} \mathrm{LnFAg}+ \\
\beta_{3} \mathrm{LnFFE}+\beta_{4} \mathrm{LnNDHM}+\delta_{1} \mathrm{SJF}+\delta_{2} \mathrm{TRSd}+\delta_{3} \mathrm{BSd}+ \\
\delta_{4} \mathrm{SRSd}+\delta_{5} \mathrm{BLsSd}+\mu_{1} \\
\text { LnSSFDOEP }=\left(\frac{\mathrm{Pi}}{1-\mathrm{Pi}}\right)=\mathrm{Ln} \beta_{5}+\beta_{6} \mathrm{LnFInc}+ \\
\beta_{7} \mathrm{LnFAg}+\beta_{8} \mathrm{LnFFEd}+\beta_{9} \mathrm{LnNDHM}+\delta_{6} \mathrm{SJF}+ \\
\delta_{7} \mathrm{TRSd}+\delta_{8} \mathrm{BSd}+\delta_{9} \mathrm{SRSd}+\delta_{10} \mathrm{BLsSd}+\mu_{2}
\end{gathered}
$$

Where:

$$
\text { SSFDCFG : The Small-Scale Fishermen Decision in }
$$
Choosing Fishing Gear and 0, others

SSFDOEP : The Small-Scale Fisherman Decision in selecting Outboard Engine Power and 0, others

About $\beta_{0}$ dan $\beta_{5}$ is intercept $\beta_{1}, \ldots, \beta_{4}$ and $\beta_{6}, \ldots, \beta_{9}$ is regression coefficient of independent variables, $\delta_{1}, \ldots, \delta_{710}$ is coefficient of dummy variable, $\mathrm{Pi}$ is probability with a value between 0 and 1, FInc is Fishermen Income (IDR), FAg is Fisherman Age (year), FFEd is Fisherman Formal Education (year), NDHM is the Number of Dependent Household Members (person), Dummy a side job of fishermen: SJF: 1 for Side Jobs; 0 for other, Dummy difference in the area where the fisherman lives: TRSd: 1 for Tanete Rilau Sub-district; 0 for others, BSd: 1, for Barru Sub-district; 0 for others, SRSd: 1, for Soppeng Riaja Sub-district; 0 for others, BLsSd: 1, for Balusu Sub-district; 0, for others, $\mu_{1}$ dan $\mu_{2}$ is disturbance error. The goodness of fit model was calculated by using adjusted $\mathrm{R}^{2}$ (Gujarati et al., 2009):

$$
\text { Adjusted R }{ }^{2}=1-\left(1-R^{2}\right) \frac{(n-1)}{(k-1)}
$$

Where:

$$
\begin{aligned}
& \text { Adjusted } \mathrm{R}^{2}: \text { Adjusted determination coefficient } \\
& \mathrm{k} \\
& \begin{array}{ll}
\text { : } & \text { Number of variables (not includes } \\
& \text { intercept) } \\
\mathrm{n} & : \text { Sampling numbers }
\end{array}
\end{aligned}
$$

The hypothesis testing of the regression coefficients together used F-test with a certain confidence level (Gujarati et al., 2009):

$$
\begin{gathered}
\text { Ftest }=\frac{\mathrm{ESS} /(\mathrm{k}-1)}{\mathrm{RSS} /(\mathrm{n}-\mathrm{k})} \\
\text { F table }[(\mathrm{k}-1):(\mathrm{n}-\mathrm{k}) ; \alpha]
\end{gathered}
$$

Testing on the partial regression coefficients was used t-test with a certain level of confidence (Gujarati et al., 2009):

$$
\begin{gathered}
\mathrm{t} \text { test }=\frac{\beta_{\mathrm{i}}}{\mathrm{S} \beta \mathrm{i}} \\
\mathrm{t} \text { table }[(\mathrm{n}-\mathrm{k}) ; \alpha / 2]
\end{gathered}
$$

Where:

$\beta_{i}$ : The regression coefficient of $i$

$S \beta_{\mathrm{i}}$ : The stand art errors of regression coefficient of $i$

Furthermore, multicollinearity test was using the Variance Inflation Factor (VIF) method (Gujarati et al., 2009):

$$
\mathrm{VIF}=\frac{1}{1-\mathrm{R}_{\mathrm{j}}^{2}}
$$

$\mathrm{R}_{\mathrm{j}}^{2}$ was received from auxiliary regression between the independent variables and dependent variables where if $\mathrm{VIF}<10$, it meant there was not multicollinearity (Gujarati et al., 2009). In the meanwhile heteroscedasticity test is conducted in disturbance variable form once variance of disturbance variable $\left(\sigma_{i}^{2}\right)$ did not know. Thus, the residual $\left(\hat{\mathrm{e}}_{\mathrm{i}}{ }^{2}\right)$ of regression results as proxy of residual $\hat{e}_{i}^{2}$ (Gujarati et al., 2009):

$$
\begin{aligned}
\operatorname{Lnê}_{i}^{2} & =\operatorname{Ln}^{2}+\beta \operatorname{LnX} X_{i}+v_{i} \\
& =\alpha+\beta \operatorname{Ln} X_{i}+v_{i}
\end{aligned}
$$

If the coefficient of $\beta$ not significance through t-test, therefore, it can be concluded not heteroscedasticity. Instead, if $\beta$ significant, hence, the model contains heteroscedasticity (Gujarati et al., 2009).

\section{RESULTS AND DISCUSSION}

The results of multicollinearity testing with VIF (Variance Inflection Factor) method do not show or indicate multicollinearity or double collinearity, VIF values $<10$ Table 1 . As for heteroscedasticity testing using park test (Gujarati et al., 2009) is the error variable as dependent variable is re-created with each independent variable and yields the coefficient value $(\beta)$ is not significant it can be concluded there is no heteroscedasticity Table 1 . In the measurement of goodness of fit that is adjusted $\mathrm{R}^{2}$ (Gujarati et al., 2009) 
J. Eng. Applied Sci., 15 (2): 574-580, 2020

Table 1: Tests analysis of multicollinearity and heteroscedasticity

\begin{tabular}{|c|c|c|c|c|}
\hline \multirow[b]{2}{*}{ Independent variables } & \multicolumn{2}{|c|}{ Fishing gear } & \multicolumn{2}{|c|}{ Outboard engine power } \\
\hline & VIF test & Coefficient Park test & VIF test & Coefficient Park test \\
\hline Fishermen income & 1.369 & $-0.098^{\mathrm{ns}}$ & 1.369 & $-0.016^{\mathrm{ns}}$ \\
\hline Fisherman age & 1.253 & $-0.045^{\mathrm{ns}}$ & 1.253 & $-0.011^{\text {ns }}$ \\
\hline Fisherman formal education & 1.121 & $-0.002^{\text {ns }}$ & 1.121 & $-0.002^{\text {ns }}$ \\
\hline Dependent household members & 1.088 & $-0.003^{\text {ns }}$ & 1.088 & $-0.004^{\mathrm{ns}}$ \\
\hline Dummy a side job of fishermen & 1.080 & $-2.988^{\text {ns }}$ & 1.080 & $-3.300^{\text {ns }}$ \\
\hline Dummy Tanete Rilau sub-district & 1.269 & $2.988^{\mathrm{ns}}$ & 1.269 & $3.300^{\text {ns }}$ \\
\hline Dummy Barru sub-district & 1.366 & $2.988^{\text {ns }}$ & 1.366 & $3.300^{\text {ns }}$ \\
\hline Dummy Soppeng Riaja sub-district & 1.099 & $2.988^{\text {ns }}$ & 1.099 & $3.300^{\text {ns }}$ \\
\hline Dummy Balusu sub-district & 1.436 & $2.988^{\mathrm{ns}}$ & 1.099 & $3.300^{\text {ns }}$ \\
\hline
\end{tabular}

therefore there was not heteroskedasticity, instead, if the value of b by using Park test significant there was heteroskedasticity, ns is not significant

Table 2: Estimation of regression with Logit Model analysis

\begin{tabular}{|c|c|c|c|c|c|}
\hline \multirow[b]{2}{*}{ Independent variables } & \multirow[b]{2}{*}{ ES } & \multicolumn{2}{|l|}{ Fishing gear } & \multicolumn{2}{|c|}{ Outboard engine power } \\
\hline & & Coefficient (b) & t-test & Coefficient (b) & t-test \\
\hline Fishermen income & + & $0.366^{* * *}$ & 7.130 & $0.395^{* * *}$ & 7.787 \\
\hline Fisherman age & - & $-0.126^{\mathrm{ns}}$ & -0.965 & $-0.073^{\mathrm{ns}}$ & -0.035 \\
\hline Fisherman formal education & + & $0.075^{\mathrm{ns}}$ & 1.120 & $0.131^{* *}$ & 2.010 \\
\hline Dependent household members & - & $0.112 * *$ & 2.152 & $0.080^{\mathrm{ns}}$ & 1.572 \\
\hline Dummy a side job of fishermen & + & $0.074^{\mathrm{ns}}$ & 1.161 & $0.073^{\text {ns }}$ & 1.171 \\
\hline Dummy Tanete Rilau sub-district & + & $-0.088^{\mathrm{ns}}$ & -1.335 & $-0.092^{\mathrm{ns}}$ & -1.429 \\
\hline Dummy Barru sub-district & + & $-0.203 * *$ & -2.913 & $-0.238 * * *$ & -3.504 \\
\hline Dummy Soppeng Riaja sub-district & + & $-0.206^{\mathrm{ns}}$ & -1.645 & $-0.189^{\text {ns }}$ & 1.541 \\
\hline Dummy Balusu sub-district & + & $-0.480 * * *$ & -6.269 & $-0.460 * * *$ & -6.156 \\
\hline Intercept & & & $-3.586^{* * *}$ & & $-4.220 * * *$ \\
\hline F-test & & & 23.304 & & 25.989 \\
\hline Adjusted $\mathrm{R}^{2}$ & & & 0.620 & & 0.646 \\
\hline n & & & 124 & & 124.000 \\
\hline
\end{tabular}

is the independent variables in the traditional fishermen decision function model in choosing fishing gear and outboard machine technology presented can explain each of the percentage of the contribution of independent variables (catch income, age of fisherman, formal education of fisherman, number of dependent household members, dummy of fisherman's side job, dummy difference of fisherman residence area) $64.6 \%$ to variation independent variable while others $35.4 \%$ is a contribution of other factors not included in the model Table 2.

The F-test results Gujarati et al. (2009) indicate that the estimation of factors influencing small-scale fishermen decision in selecting outboard engine technology in the Western coastal area of Barru district significantly influenced the level error significance of $1 \%$ Table 2. It can be interpreted that all independent variables simultaneously have a significant effect on household income of fishermen. Furthermore, individual (partial) effects of each of the independent variables on small-scale fishermen decision in selecting fishing technology are used t-test (Gujarati et al., 2009).The goodness of fitthat is adjusted $\mathrm{R}^{2}$ the independent variables in small-scale fishermen decision function model in selecting technology of outboard engine technology in West coastal area of Barru district which is presented to explain each of the percentage of free donation contribution percentage of $64.6 \%$ to variation variables while the other $35.4 \%$ is a contribution of other factors not included in the model Table 2.

Variable income of small-scale fisherman catch in West coastal area of Barru district have a positive effect of level error significance of $1 \%$ or confidence level 99\% to traditional fisherman decision in choosing fishing gear technology (longline and gill net). This is in line with the expectation that every increase of fishermen catch income of $1 \% \mathrm{n}$ will increase the decision of small-scale fisherman in choosing the fishing gear by $0.366 \%$. In this case the motor boat fishermen choose longline fishing and boat fishermen without motor selecting gill net in increasing the production of the catch. Winarti and Permadi (2013) found that the fishermen decisions in Muncar, Banyuwagi district has preferred to select purse seine in fish capture and to support fish production in their region. Variable of fishermen's age has not significant effect on the fishermen decisions in selecting fishing gears. A similar fishermen decision has been reported in Elmina Ghana (Acquah and Abunyuwah, 2011). Another case by Sudarmo et al. (2015) finding found that fishing seasons, fuel use, ice availability and equipment significantly affected the development of 
fishing operations using arad nets in Tegal district while the size of fishing gear, clean water use and crew did not significantly affect.

Another case of small-scale fisherman decision in choosing the technology of outboard engine strength (the size of 4.5, 5, 6 and $7 \mathrm{PK}$ ) is influenced positively to level error significance of $1 \%$ that affect the production of catch and Salas and Charles (2008) in Yucatan Mexico that ship size and motor strength are strongly associated with small-scale fishing variations. The small-scale fishing age in the West coast coastal area of Barru district has no significant effect on the decision of fishermen in selecting fishing gears and outboard engine power. This is in contrast to the findings by Acquah and Abunyuwah (2011) finding that the decision of the community to be a fisherman in the central Elmina Region of ghana that the respondent age, marital status and monthly income variables have no significant effect.

The formal education of fishermen positively influences small-scale fishermen's decision in choosing technology of outboard engine power, meaning that the higher level of formal education of fishermen, hence, there is a tendency of small-scale fishermen decision in responding to the technology to respond increasingly the size of 4.5, 5, 6 and 7 PK. This result is certainly in line with the findings by Akanni (2008) in Nigeria that the educational level of fishermen determines the use of motorized fishing technology while the findings by Mazuki et al. (2012) in Malaysia that the factor limiting technology transfer is due to illiteracy that is strongly associated with the educational achievements of fishermen.

The number of family members borne positively affects the level of small-scale fishermen's decision in selecting fishing gear technology. The number of family members will decrease the decision in choosing the technology of fishing gear. Nevertheless, the decision to choose or use fishing gear is the priority to increase the number of catches, so as to increase their income. As the number of family members is the responsibility of the head of the family, it encourages the spirit of work to increase income.

Dummy differences in the area where small-scale fishermen both Barru sub-district Sumpang Binangae village and Balusu sub-district Takalasi village negatively affect the small-scale fishermen decision in choosing the technology of fishing gear and outboard engine power. Negative influence is on dummy of Barru and Balusu sub-district to the decision of fishermen to choose catching tools and outboard engine power, other area of Tanete Rilau and Soppeng Riaja sub-districts have no significant effect to fisherman decision in selecting fishing technology while Mallusetasi sub-district as comparison of small-scale fisherman residence area. Fisherman's residence areas may influence fishermen in selecting fishing locations as they depend on their capture technology as Eales and Wilen (1986) finds that fishermen chose Northern coast of California to catch pink shrimp as well as a choice of long line fishing areas in Hawaiian waters (Pradhan and Leung, 2004).

\section{CONCLUSION}

The small-scale fishermen's decision in selecting the capture technology (longline and gill net) both in the Western coastal area of Barru district is positively influenced by the income of catching businesses and the number of members covered and negatively by the different areas of the fisherman's residence. In contrast, small-scale fishermen's decision in selecting outboard machine power technology $(4.5,5,6$ and $7 \mathrm{PK})$ is positively influenced by the income of catching businesses and the number of members covered and negatively by regional differences, selected by small-scale fishermen will be greatly influenced by the income of catching businesses in improving their welfare as well as the number of family dependents as motivation in working in the capture fisheries sector.

In improving the household economy of small-scale fishermen in the western coastal area of Barru district there is a need for the support of fishing gears such as longline fishing and gill net that are environmentally friendly based on biological, technical, social, economic and environmental aspects of small-scale fishermen as well as the power of outboard engine with size 15-20 PK to reach the fishing ground so as to increase production and income from the catch. For that needed the help of stockholder or local government with equitable and fair all the fishermen in the region.

\section{REFERENCES}

Acquah, H.D. and I. Abunyuwah, 2011.. Logit analysis of socio-economic factors influencing people to become fishermen in the central region of Ghana. J. Agric. Sci., 56: 55-64.

Akanni, K.A., 2008. Catch levels and capital investment of artisanal fishermen in Lagos State, Nigeria. Turk. J. Fish. Aquat. Sci., 8: 361-368.

Barnes-Mauthe, M., K.L. Oleson and B. Zafindrasilivonona, 2013.. The total economic value of small-scale fisheries with a characterization of post-landing trends: An application in Madagascar with global relevance. Fish. Res., 147: 175-185.

Bolaky, D., 2006. Small scale longline fishing technique for the artisanal fishermen in Mauritius. Fisheries Training Programme, United Nations University, Tokyo, Japan. http:/www.unuftp.is/static/fellows/ document/bolaky2006b_prf.pdf

Borooah, V.K., 2002. Logit and Probit: Ordered and Multinomial Models. Sage University, Machala, India, ISBN:9780761922421, Pages: 104. 
DeMaris, A., 1992. Logit Modeling: Practical Applications. Sage, Newbury Park, California, ISBN:9780803943773, Pages: 87.

Eales, J. and J.E. Wilen, 1986.. An examination of fishing location choice in the pink shrimp fishery. Mar. Resour. Econ., 2: 331-351.

Ele, I.E. and M.O. Nkang, 2014.. Analysis of production determinants and technical efficiency in crayfish production in the lower cross river Basin. Niger. J. Res. Humanities Soc. Sci., 2: 30-36.

FAO., 2016. Small-scale fisheries around the world. Food and Agriculture Organization, Rome, Italy. http://www.fao.org/fishery/ssf/world/en

FAO., 2016. Sustainable small-scale fisheries. Food and Agriculture Organization, Rome, Italy. http://www.fao.org/policy-support/policy-themes/ sustainable-small-scale-fisheries/en/

Gebremedhin, S., M. Budusa, M. Mingist and J. Vijverberg, 2013.. Determining factors for fishers income: The case of Lake Tana, Ethiopia. Int. J. Curr. Res., 5: 1182-1186.

Gujarati, D.N., D.C. Porter and S. Gunasekar, 2009. Basic Econometics. 5thEdn., McGraw-Hill Education, Pennsylvania Plaza, New York, USA., ISBN:9780071333450, Pages: 886.

Hilborn, R. and M. Ledbetter, 1985.. Determinants of catching power in the British Columbia salmon purse seine fleet. Can. J. Fish. Aquat. Sci., 42: 51-56.

Khder, M.M., 2015. An efficient approximate method for solving fractional variational problems. Applied Math. Modell., 39: 1643-1649.

Lane, D.E., 1988.. Investment decision making by fishermen. Can. J. Fish. Aquat. Sci., 45: 782-796.

Lopes, P.F.M. and A. Begossi, 2011.. Decision making processes by small scale fishermen on the Southeast coast of Brazil. Fish. Manage. Ecol., 18: 400-410.

Matiya, G., Y. Wakabayashi, D. Ng'ong'ola and N. Takenouchi, 2005. A logit analysis of socio-economic factors influencing people to become fisherman around lake Malombe in Malawi. J. Applied Sci. Res., 1: 18-32.

Mazuki, R., N. Man, S.Z. Omar, J. Bolong, J.L. D'Silva, H. Azril and M. Shaffril, 2012. Technology adoption among fishermen in Malaysia. J. Am. Sci., 8: 1-4.

Mistiaen, J.A. and I.E. Strand, 2000.. Location choice of commercial fishermen with heterogeneous risk preferences. Am. J. Agric. Econ., 82: 1184-1190.

Mukarrama, M.M.F., J.M.M. Udugama, U.K. Jayasinghemudaligae, S.M.M. Ikram and S.N. Dissanayake, 2013.. Assessing the household food security of marine fisheries sector in Sri Lanka: Case of muslim fishing community in the Beruwala Divisional Secretariat Division. Sri Lanka J. Aquat. Sci., 15: 61-73.
Ofori-Danson, P.K., D.B. Sarpong, U.R. Sumaila, F.K. Nunoo and B. Asiedu, 2013.. Poverty measurements in small-scale fisheries of Ghana: A step towards poverty eradication. J. Curr. Res. J. Soc. Sci., 5: 75-90.

Oladimeji, Y.U., Z. Abdulsalam, M.A. Damisa and D.F. Omokore, 2015.. Analysis of food consumption pattern among rural fishery households: A panacea to poverty alleviation in North central Nigeria. Asian J. Agric. Extension Econ. Soc., 6: 102-110.

Pomeroy, R.S. and N. Andrew, 2011. Small-Scale Fisheries Management: Frameworks and Approaches for the Developing World. Centre for Agriculture and Bioscience International, Wallingford, UK., ISBN:9781845936082, Pages: 247.

Pradhan, N.C. and P. Leung, 2004.. Modeling trip choice behavior of the longline fishers in Hawaii. Fish. Res., 68: 209-224.

Rahim, A. and D.R.D. Hastuti, 2018. Applied multiple regression method with exponential functions: An estimation of traditional catch fishermen household income. J. Phys. Conf. Ser., Vol. 1028, No. 1. 10.1088/1742-6596/1028/1/012177

Rahim, A., D.R.D. Hastuti and N. Bustanul, $2018 .$. Estimation of household consumption expenditure of small-scale fishermen in Indonesia. Russ. J. Agric. Soc. Econ. Sci., 11: 375-383.

Rahim, A., D.R.D. Hastuti, W.. Firmansyah and A. Syam, 2019.. The applied of cobb-douglas production function with determinants estimation of small-scale fishermen's catches production. Int. J. Oceans Oceanogr., 13: 81-95.

Salas, S. and A. Charles, 2008. Are small-scale fishers profit maximizers?: Exploring fishing performance of small-scale fishers and factors determining catch rates. Proceedings of the 60th International Conference on Gulf and Caribbean Fisheries Institute, November 5-9, 2007, Punta Cana, Dominican Republic, pp: 118-124.

Saul, S. and D. Die, 2016.. Modeling the decision-making behavior of fishers in the reef fish fishery on the west coast of Florida. Hum. Dimensions Wildl., 21: 567-586.

Sudarmo, A.P., M.S. Baskoro, B. Wiryawan, E.S. Wiyono and D.R. Monintja, 2015.. Analysis of production factors of small-scale fisheries using arad nets in Tegal City, Indonesia. Developing Country Stud., 5: 98-104.

Tveteras, R. and H. Eggert, 2001. Stochastic production and heterogeneous risk preferences: Commercial fishers gear choices. Working Papers in Economics 54, Department of Economics, Goteborg University, Gothenburg, Sweden. https://gupea.ub.gu.se/handle/ 2077/2880

Winarti, L. and R. Permadi, 2013.. Distribution of fishermen household incomes (case study in Sungai Bakau village in Seruyan Hilir Timur Distric and Sungai Undang village in Seruyan Hilir Distric Seruyan Regency). ZIRAA’AH, 40: 203-221. 